\title{
GLOCALISATION IN THE SERVICE OF RESISTANT DISCOURSES: TOWARDS 'READING' WITH VOLKER KÜSTER
}

\author{
Godwin Akper \\ Systematic Theology and Ecclesiology \\ Stellenbosch University
}

\section{Abstract}

'Talking back' in a non-confrontational way, this essay engages the German theologian Volker Küster's 'reading' of what it views as resistant discourses from the global South. In the first instance, the essay attempts to 'read', with Küster, global political and social transformations since 1990, specifically looking at possible ways they have shaped theological discourses in the global South. Moving on, is Küster's 'reading' of a selected number of the latter discourses. The essay also attempts to highlight analytically, how Küster came to the conclusion that a shift occurred from contextualisation to the so-called glocalisation. Finally, based upon an own 'reading' of the discourses and drawing on the discussants' voices themselves, an argument is made for glocalisation in the service of contextualisation.

Keywords: Contextualisation; Globalisation; Glocalisation; African Theology; Black Theology; Resistant discourses; Postcolonial discourse; Feminist criticism

\section{Introduction}

German scholar Volker Küster recently published ${ }^{1}$ a very insightful article in Exchange, arguing that recent economic, political and social changes that took place around the world have already left their marks on theology. ${ }^{3}$ They have done so, he argues, specifically on so-called resistant theologies ${ }^{4}$ from the, to use Küster's term, Third World. According to

\footnotetext{
'Reading' here refers to an attempt to understand and interpret what is written by another person. The concept of 'talk back' is taken from Maluleke and Nadar to delineate the importance of resistance in the discourses under review. Cf. Maluleke \& Nadar, "Alien Fraudsters in the White Academy. Agency in Gendered Colour", Journal of Theology for Southern Africa 120 (November 2004:5-17).

2 Volker Küster, "From Contextualization to Glocalization: Intercultural Theology and Postcolonial Critique", Exchange 45 (2016:203-226).

Küster, "From Contextualization to Glocalization", 203.

4 This is how most of those engaging these theologies regard them. In postcolonial discourses, it is not necessarily completely wrong, but neither is it completely acceptable to many that one may name and speak for the "other". Therefore, the concept of 'Third World' being a description of developing countries/economies of the so-called global South is increasingly being challenged. Maluleke \& Nadar (South African Black male and South African Indian female theologians respectively) would summarise the imports of these theologies as resistant and libel theologies, dominated, but fighting for survival on an unfair White epistemological terrain. See Maluleke \& Nadar, "The Agency of the Oppressed Discourse: Consciousness, Liberation and Survival in Theological Perspective", Journal of Theology for Southern Africa 120 (November 2004:2-3); "Alien Fraudsters in the White Academy: Agency in Gendered Colour", Journal of Theology in Southern Africa, 120 (November 2004:5-17). In this essay, I refrain from using sources from White scholarship and from the global North simply because it is argued by black and African theologians that Africans should be able and motivated to 'drink' from their 'own wells'.
} 
Küster, when considering the fact that some of the interlocutors of a number of these theologies have become obsolete, such theologies have either deteriorated or transformed from local, cultural, or particularistic to globalised theologies. ${ }^{5}$ Küster lists such theologies as, among others, inculturation, ${ }^{6}$ contextual, liberation, feminist, postcolonial theologies and hermeneutics. Globalisation is understood by Küster to refer to a discourse involving "many-folded connections, mutual dependencies or permanent exchanges" between what was previously proposed to be local, contextual and community-like but is now globalised. From his arguments, it appears that Küster is under the impression that the various theologies he reviewed had a shared main agenda, namely to particularise and localise global intellectual discourses. Therefore, he argues and concludes that such particularistic and localisation projects could not be sustained by either earlier or later generations of theologians, as the (particular and local) issues the theologies were designed to address became global issues which called for synergy. Küster thus thinks that inculturation, reconstruction, gender, race, feminist, liberation or contextual theologies and hermeneuti no longer exist cs, but what appeared in their place were globalised discourses. 'Pitching tent' with postcolonial criticism as "a meaningful continuation of contextual theologies in the era of globalisation", 7 Küster is of the view, for example, that "inculturation theology points at a way from contextualisation ${ }^{8}$ to globalisation". 9 I will argue that the resistant theologies/hermeneutics here referred to, were approached by Küster as discourses. Küster 'read' discourses of a select number of discussants of proponents of the theologies. This approach led him to the conclusion that there has been continued transformation of these theologies into others, terminating in globalised theology. While not denying the fact these theologies had undergone transformation, a broader 'reading' of their tasks expressed in the discourses will, however, reveal that they are still hovering around contextualisation and have not necessarily been totally taken up into globalisation in the way Küster portrays them in his article.

\section{On Global Political and Social Transformation}

Like South African theologian Tinyiko Sam Maluleke, ${ }^{10}$ Küster identifies the perceived end of the Cold War symbolised in 1989/90 by the fall of the Berlin wall, as the dawning of a new world order. The latter, Küster argues quite eloquently, signalled a form of hybridity of political and economic life of the former communist East and the capitalist West as they

5 Of course, Kwok Pui-Lan (originally from the global South, but currently residing in the USA) also makes a case for a Global theology, but not as globalisation theology. For the difference between these two concepts see her "Teaching Global Theology in a Global Perspective", in: Kwok Pui-Lan, Cecilia Gonzalez-Andrieu \& Dwight N Hopkins (eds.) Teaching Global Theologies. Waco, TX: Baylor University Press (2015:12-13).

6 Küster, "From Contextualization to Glocalization", 226.

6 Küster, "From Contextualization to Glocalization", 226.

6 'Inculturation' is understood here in the way 'Third World' theologians, especially in Africa, use it. The South African theologian, Buti Tlhagale describes Inculturation as "the use of African Culture as a medium of communicating the gospel message. Inculturation thereby also seeks to give a purified meaning, in conformity wit Christian truths, to African cultural practices". See Tlhagale, "Inculturation: Bringing the African Culure into the Church", in: African Theologies in Transformation edited by Ernst Conradie, Stellenbosch : EFSA (2004:43-67).

7 Küster, "From Contextualization to Glocalization", 226.

8 This refers to the use of context to delineate a complex or otherwise theological construct, especially as it is argued in the works of those theologians in the global South under discussion.

9 Küster, "From Contextualization to Glocalization", 226.

10 Tinyiko S Maluleke, "Black and African Theologies in the New World Order: A Time to Drink from our Own Wells", Journal of Theology for Southern Africa (JTSA), 96 (November 1996:3-19). 
both scrambled for control of the South, for which the latter was later to bear the brunt of negative consequences. Within the South itself, the gap between the rich and the poor became wider despite the fact that the world became a global village through superior communication media technology. ${ }^{11}$ Conscious of the fact that the West and East are not as yet free from conflicts and power contestations, Küster further explains that "[T]he possible allegation that this is [simply] a Eurocentric perspective is refuted by the strong connection of the conflicts between East and West, and North and South". ${ }^{2}$ He reiterates that the power consolidation following the fall of the Berlin Wall was the work of already wellestablished power blocs. While European Union (EU) was formed with a cooperate interest towards the East, taking with it most of what had until then belonged to communist powers. Russia, on the other hand, emerged as a 'new' super power, leaving behind a number of the "former Warsaw Pact states" for the EU. ${ }^{13}$ The USA, according to Küster, was preoccupied with its "War on Terror" in the Middle East, protecting its (the USA's) interests in the massive oil resources in the Gulf region. For Küster, these changes, in one way or another, had implications for thought patterns and ideologies in Third World countries. This coincided with a widespread renewed sense of national and cultural identity, as refugee crises arising from the power contestations among the 'world's giants' scattered citizens of developing countries into the global North.

Küster's arguments, put in context, portray the impact of global political and economic transformation have, on what is considered by some theologians in the global South, as contextual (or resistant as Maluleke \& Nadar call them) theologies. He succinctly summarised his conviction, also taking note of the views of many in the global South, in the following words: '...theologies which consider themselves as contextual undergo deep transformations from localisation to deterritorialisation, from being mono-cultural to hybridity and from being community centered to multiple belongings'. ${ }^{14} \mathrm{He}$ traced this major shift from "contextualisation to glocalisation" to the works of leading theologians from the global South like Musimbi Kanyoro (Kenya), Musa Dube ${ }^{15}$ (Botswana), Kwok Pui-Lan (resident in USA but Asian by race) and RS Sugirtharajah (United Kingdom).

The 'global' citizenship of some of the above-named theologians underscores the point stressed in Küster's article, that there is a consistent shift away from local to global, from community-based (centred) to "deterritorial", as it is in the case of Kwok Pui-Lan and RS Sugirtharajah. There are also a number of events, such as migration, political and socioeconomic transformations in countries like South Africa (like the demise of a separate development ideology called apartheid and recently the fall of Jacob Zuma), ${ }^{16}$ in Zimbabwe (especially the unexpected peaceful fall of Mugabe); the four times historic peaceful civil to civil transition in Nigeria, and many others call for a new theological thinking in Africa and the rest of the global South as argued by Küster in his article. Perhaps, the lists of events that ushered in the so-called new order is endless. One could add to the events mentioned by Küster, to argue further that major transformations are ongoing in the global South, that also call into question the continued relevance of earlier theologies that seek to

\footnotetext{
Küster, "From Contextualization to Glocalization", 204.

Küster, "From Contextualization to Glocalization", 204.

Küster, "From Contextualization to Glocalization", 204.

Küster, "From Contextualization to Glocalization", 203.

See her, "Looking Back and forward: Postcolonialism, Globalization, God and Gender", Scriptura: International Journal of Bible, Religion and Theology in Southern Africa (2006/2:178-193).
}

16 Which signifies a shift from embrace of nepotism, dictatorial rule to accountable democratic leadership that Küster refers to in the article under discussion. 
problematise post-coloniality (Dube), liberation (Mosala, Boesak, Mafokeng, among others); inculturation (Musimbi), as the events that reflect some of the transformations that occurred at the beginning of the so-called new order appeared to have dampened earlier enthusiasm for those theological 'projects'.

But did such a new world order really persist? If the fall of the Berlin wall was significant in bringing to an end an old era, is Donald Trump's threat during his first week in office as the USA's $45^{\text {th }}$ president to raise a wall in North America between the USA and Mexico, a mark of the rebirth of the 'old world order'? Perhaps this could be dismissed for the fact that many within USA criticise Trump, while other media commentators regard him as a 'deranged politician'. Yet, the Columbia SC (USA) racial protests, the reaction of the President of Mexico, by cancelling his initial visit to Whitehouse in protest; the declaration of Jerusalem as the capital city of the State of Israel by Trump's administration and the reactions that trail that declaration from the Arab League of Nations; the release of the The End is not Yet published by a leading South African theologian, John De Gruchy, ${ }^{17}$ depicting Trump's views as indeed representing the views of elites in the USA further underscore the point that another world order or a reversal of the an existing one may have erupted. Similarly, on January 26, 2017, in her first and most powerful speech to date, United Kingdom's (UK) Theresa May, addressed Republican Law makers and this seemed by all indications to favour the re-establishment of another but redefined imperial world order. In the latter, 'Global Britain', as she calls it, would take the lead with the USA as its soul partner. Again, it could be argued that May represents the right wing conservative view from the global North. However, true as that may be, the Brexit processes and the ongoing re-alignment that follows it, the decision of the South African Parliament to vote for reversal of traditional land ownership in some communities in South Africa, stressing local community-centredness, are events pointing towards another world order based on local interests, not only in the global North, but also in the global South.

In their separate foreign policy statements, both the British Prime Minister and the USA President are apparently clear on the kind of world order with which their countries seek to establish or engage. May explicitly says it is the relationship between the UK and USA that "defined the modern world". ${ }^{18}$ In turn, Trump insists that it is either America first, or no deal at all. I find Trump's position almost identical to that of May of Global Britain. The world is again, as it has in fact always been during and after the Cold War, defined in accordance with the USA and UK's global interests and ideology. If this is the case, then it may be safe to argue that in reality, following the fall of the Berlin Wall, no new world order was established, but merely a realignment of interests and partners in the global North. In this sense, globalisation by USA and the UK in the years to come appears to be boiled down to "thinking globally, but acting very locally" for the benefit of one's own people. And this is the version of globalisation, I find in the resistant and contextual discourses succinctly analysed by Küster in his "From Contextualization to Glocalization". 19 In the next section of this essay, I turn in more detail to Küster's 'reading' of how the events described above impacted on, and transformed Third World theologies.

\footnotetext{
17 John De Gruchy, The End Is Not Yet. Standing Firm in Apocalyptic Times. Minneapolis: Fortress Press, \{repr. in Cape Town by The Methodist Publishing House\} 2017.

18 Theresa May, "Full Text of Theresa May's Speech to 'Congress of Tomorrow' Conference”, Philadelphia, USA, January 26, 2017. Available on: http://uk.businessinsider.com/full-text-theresa-mays-speech-to-therepublican-congress-of-tomorrow-conference-2017-1?IR=T \{accessed 20/4/17\}. 


\section{On Changing Third World and Theological Discourses}

"I think that what Africa will need is the ability to drink from our own wells as it were." 20

Küster provides a very insightful, comprehensive and what could be described as an acute narrative on the changing situation of the Third World. ${ }^{21}$ Following the end of the Cold War, he asserts, the world has opened up, with only North Korea hanging on to its selfimposed isolation. $^{22}$ The agitation for regime changes, to replace military dictatorship in Africa appears to decrease. There are track records of peaceful political transitions in most of the countries of the Third World. One finds an increase in developing economies making news - such as China joining the G20 and South Africa and Brazil showing significant economic growth with greater potential envisaged for other countries beyond 'the southern tip' of Africa. Theologically-speaking, as may be expected, one also finds a transformational shift and in the theological focus and discourse of theologies of the Third World. An example is the views of Laurenti Magesa (from Africa), who "claims that African traditional religion is a world religion to demonstrate that the worldview and the values of his continent contribute genuinely to the global knowledge economy". ${ }^{23}$ With regard to the categories of 'globalisation' and 'empire', Küster argues that helpful as these concepts may be, the idea of 'empire' as a hermeneutical key to understanding changes in the global world, presents the "risk of falling into a trap of a monocausal interpretation pattern of a situation that needs to be analysed from multiple perspectives". ${ }^{24}$ Globalisation, he argues, is weak because of its "unilateral focus on socio-economic and political factors accompanied by a disregard of cultural and religious factors" 25 as resistant or 'counter-movements'. Küster furthermore argues that "local cultures strengthen themselves in hybrid forms as counter movements, which make all cultural analysis needing a complex hermeneutics of difference to delineate the new mixtures adequately". His conclusion on this matter is that:

[I]f one wishes to analyse and understand the situation of the Third World, it is better to pay attention to ethnicity, fundamentalism and the reconstruction of hybrid identities, the formation of local elites and the deterioration of the position of the urban proletariat, which works in the sweat-shops and call-centres of the megacities. ${ }^{26}$

Nothing is to be gained from denying the fact that the developing world has undergone the changes/transformations discussed by Küster. However, his initial assumption that resistant

20 Tinyiko S Maluleke, "Black and African Theologies in the New World Order. A Time to Drink from our own Wells', Journal of Theology for Southern Africa 96 (November 1996:17).

21 To Küster, the so-called Third World refers to developing economies of countries in Africa, Asia, the Middle East and Latin America (see, 'From Contextualization to Glocalization", 205-207). However, according to Amin Samir, from the end of the Cold War and its attendant consequences, Africa appears to be in the Fourth World (whatever this means)! See, Amin Sanir, "A World in Chaos" Voices from the Third World XVIII:2 (December, 1995:160-182).

22 Küster, "From Contextualization to Glocalization", 205.

23 Küster, "From Contextualization to Glocalization", 206. Also, Magesa, African Religion. The Moral Traditions of Abundant Life. Maryknoll, NY: Obis 1997.

24 Küster, "From Contextualization to Glocalization", 206.

25 Küster, "from Contextualization to Glocalization”, 206.

26 Küster, "From Contextualization to Glocalization", 207. 
and contextual theologies themselves transformed from being contextual theologies to becoming globalised theologies affects, in my opinion, his fair assessment of the situation in the Third World as regards doing theology in that context. Therefore, his description of the transformation of the Third World in the era of globalisation logically leads him to the conclusion expressed in the quotation above.

Küster also dismisses the idea of 'empire' on the ground that it focuses only on the USA's global domination. However, one has to ask whether this is really the interpretation of 'empire' by theologians of the Third World. When Black theologians in South Africa speak about Afrikaner nationalism and how the ideology led to disinheritance and genocide of the indigenous people - an act legitimised by a hyper-Calvinistic theology - were they referring to the USA? Related questions to ask are: with regard to the recent speech of Theresa May in Philadelphia referred to above and the ongoing Brexit processes and the ideology behind the intention to withdraw from EU, will it still be helpful to argue to the contrary, that the idea of empire is fresh in the minds of global superpowers as it was before the end of the so-called Cold War? As was seen, both May and Trump made it clear to the world that their countries come first. It is Britain first and America first. When May speaks of global Britain, what does she mean? What would a global Britain in the twenty-first century mean to the global South? Küster refers to the massive cross-border migration of different groups as a contributor to the intermingling of local culturing identities. While this may be the case, there is also another side to it. Migrants to the global North, despite the apparent appearance of being clothed in imperial-capitalist identities of the powerful global North are nonetheless aliens in those cultures. At most, they end up in what the theologian Miguel de la Torres refers to as ou topos (utopia) - meaning no place - in a supposedly superior place! Hear what he has to say with regard to Cuban-American migrants:

...the Cuban-American creates a hyphenated identity, attempting to reconcile two distinct and separate cultures into one being. This locution erects within our very being a schizophrenic (Latin for 'split mind') existence. This phenomenon was manifested during my first trip to Cuba, my homeland, some forty years after I left. ...I was approached by one of the city jineteros (street hustlers) who asked me where I was from... With pride I stated I was from here from this very city; to which he replied, "you may be from Cuba, but obviously not Cuban." ...I realise that I will always be too Cuban ever to be fully accepted within the United States and too Americanised ever to be accepted by my native compatriots. In effect, I occupy utopia (Greek for 'no place' -ou topos), for literally there is no place on earth to which I and other US scholars of color (sic) can belong. ${ }^{27}$

Reading the 'confessions' of De la Torre and others, ${ }^{28}$ one could easily discern the primordial stigma that is placed on the faces of nearly all the people of the South that may last for the unforeseeable future, no matter where they migrate to. In terms of the hybridity that

27 Miguel A de La Torre, "Identity Cross-Dressing while Teaching in a Global Context”, in: Teaching Global Theologies, 80-81.

28 Other examples include Roy I Sano, an Asian-American, who also tells of the experiences of AsianAmericans, who in the 1950 s felt privileged by the imperial identity of becoming Americans, and the capitalist identity of being educated in an advanced and superior Euro-centric culture and worldview, had a sense of belonging to an upper superior class, but later felt rejected by that same class, because of their race, their culture, and because of their very nature of being aliens from Asia. They finally realise, according to him, that they are constituted by their own real culture: that of being Asians, and no identity is true of them, than the one they were born into. He therefore insists unapologetically that "particularity of method and focus [context] are both inevitable and necessary" \{my emphasis See Sano, "Shifts in Reading the Bible:

Hermeneutical Moves Among Asian Americans", Semeia 90/91 (2002:105-118). 
Küster proposes, the example he refers to are that of Hispanic Americans; also of Asian Americans and the various segmented structures within communities in the global South itself. Küster's argument is that the effects of pluralism - with all its ambiguities - are felt more by the people of the global South, than those of the global North.

Regarding phenomenon of globalisation, theologians of the Third World never accepted it as a helpful way forward for theological, economic and social transformation of their own people. To them, what the Third World (the global South) has seen in the so-called globalised economy is that the powerful become more powerful and the rich richer to the detriment of the people these theologies wish to serve. ${ }^{29}$ According to Allan A Boesak, one of the leading voices of Black Liberation Theology in Africa:

$[O]$ ne of the startling realities of the 'new south Africa' is not only that the rich are getting richer and the poor poorer, but that the gap between the rich, including the new black elites, and the poor is wider than ever. The legacy of apartheid continues to cast a long dark shadow over the lives of those who are most miserable and vulnerable. ${ }^{30}$

The main focus of resistant theologies is the emancipation of their own people. Globalisation appears to have worsened the living conditions of people in the global South. Küster is therefore right in arguing that the concept of globalisation used as a hermeneutical lens to interpret global issues is weak and lopsided towards socio-economic and political factors while at the same time it neglects cultural and religious factors. This is precisely the point of resistant theologies which argue that there is still a gap existing that needs to be attended to. It is pertinent to note that socio-economic and political factors trigger the neglect of religious and cultural factors. Accordingly, to the contextual theologians (discussed here), all these factors appear to go together. For the people of the South, globalisation did not offer a sufficient way out of any of these factors. When Magesa speaks of African traditional religion being global religions, he was not arguing for globalisation per se, but rather for the inherent value of such religions themselves, especially their contributions to theological developments before the arrival of Christian missionaries to the continent. Such religions, Magesa argues, have credentials that should be recognised as such in their own right. Yet, this point of view is criticised by some leading contemporary African Christian theologians. $^{31}$

Küster also supports his argument that the global changes have transformed the theological landscape of Third World theologies by saying that "local cultures [in the Third World] strengthen themselves in hybrid forms as counter movements, which make all cultural analysis needing a complex hermeneutics of difference to delineate it". This is one of the shortcomings resistant and contextual theologies point out in the idea of 'speaking

29 Pui-Lan reports the fact that a number of theologians of the developing global south accept the fact that deterritorialisation exists, but territorial geography still remains and they insist, especially feminist/womanist intellectuals, that their discourses continue to address particular and distinctive issues of their particular contexts. Cf. Kwok Pui Lan, "Teaching Theology a Global Perspective", 20-25

30 AA Boesak, "Truth Crushed to Earth will Rise Again: Christian Theology in South Africa- Looking Back", in: Ernst M Conradie (ed.), African Christian Theologies in Transformation. Stellenbosch, Ecumenical Foundation of Southern Africa (2004:24-25).

31 See for example, Maluleke, "Black and African Theologies in a New World Order", 15; Maluleke \& Sarojini Nadar, "Alien Fraudsters in the While Academy: Agency in Gendered Colour", Journal of Theology in Southern Africa 120 (2003:13-14). The argument of these African theologians is that by merely being in the majority (not clear here: does neither their own numerical majority or that of their religions, nor the fact that their religions are word religions, matter to the people of the South?) Statistically (numerically?), or that African religions are world religions have not mattered much to people of the so-called global South. What matters to these theologians/the people of the South (?) is their daily real life socio-economic wellbeing. 
for...'. African cultures are known for their plurality and therefore their ambiguity. This may be different from other countries like South Korea, India, Latin America, where people speak one language, and share a similar culture and so on. Although not challenged by multiplicity of languages and cultures as in Africa, Asians too, it could be argued, have multiple views on social transformation in their various contexts as Küster also admits. Whether or not there is a deliberate effort by the people of the South, who vehemently rejected globalisation, towards hegemony of views or cultures, would need further clarification beyond the ordinary description of the cultures in terms of hybridity. Furthermore, more exploration is needed to unearth how 'hybrid identities' could emerge, amongst others, from ethnic fundamentalism, as Küster suggests. ${ }^{32}$ Nevertheless, the point Küster is perhaps trying to make, is that the socio-economic and political transformation in the Third World have changed the thinking of theologians in the South from that of contextualisation to globalisation. His 'reading' of selected discourses is aimed at proving just that. In what follows, Küster's 'reading' of these discourses is analysed over against what I consider to be the actual arguments and basic thrust of resistant and contextual theologies of the South.

\section{On Resistant Theologies in Changing Contexts}

"...the category of the struggle provides the lens for reading the text in a liberating fashion, as well as the codes for unlocking the possibilities and limitations of the biblical texts.",33

- IJ Mosala

“...as we African intellectuals continue to meet to discuss ... African Christians are in the process daily of shaping a Christianity that will be at home in Africa and in which Africa will be at home.",34

- Mercy Amba Oduyoye

The quotations given as epigraphs above express the mood of theologians from the Third World. A 'reading' of the discourses that takes into cognisance, the mood with which the discourse were engaged into in the first place, would provide sharper hermeneutical lenses with which to 'read' and interpret them. Three things should be made clear: 1) theologians who engage in Third World theologies are not interested in promoting or realigning themselves to what has already been put on the table by Western theology. On the contrary, they are out to oppose and resist its perceived dominating patterns. 2) Theologians who are constructing these theologies do so in rebellion against established Westernised theologies. 3) These Third World theologies are the result of the zeal to address the spiritual and material needs of Christians from the margins, who are trying to 'find' God, so that God could 'find' them, in their situation of despair, but full of hope for a better future. Most of the discussants of these theologies think established Western theologies do not have the requisite potentials to provide answers to the real life questions of people presumed to be underprivileged. In what follows, I will attempt to 'read' Küster's view on Third World theologies in the changing world context with the aforementioned three points in mind.

See Küster, "From Contextualization to Glocalization”, 207.

3 IJ Mosala, "Biblical Hermeneutics and Black Theology in South Africa. Grand Rapids, MI: Eerdmans (1989:123).

34 Mercy Amba Oduyoye, “Christianity and African Culture”, International Review of Missions LXXXIV (January /April 1995:77). 
First of all, Küster correctly points out that "contextual theologies got entrance in the local churches and curricula of their theological seminaries only very slowly" 35 Theological Seminaries, especially the ones in Africa, are still following the curricula of their churches' home missionary boards that, to a large extent, still fund them. The situation is even more complex in West Africa. Cases in point are: Trinity Theological Seminary has been affiliated to University of Ghana, the Theological College of Northern Nigeria, to University of Jos; and the Reformed Theological Seminary, to University of Calabar (Nigeria). These are indeed state-owned universities with a broad curriculum in religious studies and naturally, degrees awarded to students from these affiliated institutions would bear the marks of the curriculum of the universities awarding the degrees as directed by accreditation and regulatory agencies of their countries. Therefore, while they may be free from structural and theological cumbersomeness of traditional churches, they are not really free from those of state agencies. Thus, not only are the curricula of theological seminaries still determined by nineteenth century missionary theologies, they are also coined by liberal and secular theories of related disciplines in the humanities.

However, Third World theologians are not practicing seminary and traditional theology. Most discussants of theological discourses of the Third World have also transcended denominational boundaries. As such, the future of contextual theologies in the developing world is not determined by what is going on in theological seminaries. Perhaps contextual theologies themselves are tired of seminary theology. What they are out to do is a theology of 'power' and of 'praxis'. That is to say, "[they] call ... not for mastering the theological canon of the West but to explore divinity through the eyes of the marginalised who have resided for centuries on the underside of the colonisers. The journey of solidarity becomes [to them] a liberative pedagogy, which can be implemented (not just by scholars of color (sic), within a global context". That the "relationship between global and contextual theologies is shaped by denominational histories, theological traditions and institutional structures" is not news to discussants of Third World theological discourses. In fact, it is this very 'theological pitfall' ${ }^{37}$ that contextual theologies seek to eliminate. Also, even a cursory 'reading' of the discourses still unearths the fact that contextual theologies are aware that such 'theological pitfalls' do not exist by accident. They (pitfalls) exist as part of a colonial residual being preserved via neo-colonial religious globalisation from above. Perhaps this amounts in part, to what Küster calls a 'complex' mixture requiring a "complex hermeneutics of difference to delineate the new mixtures adequately". Therefore, this may be the reason why Küster himself nearly fell into the pit of "overgeneralisation and simplification", 38 of what are otherwise particular but nonetheless multiple and complex theological issues, that call for contextualisation in order to attend to the specifics of each of the particular issues.

While applauding the global impact of contextual theologies as rightly proposed by Robert Schreiter, ${ }^{39}$ Küster argues that Third World theologies have multiple, but different sets of problems. These problems include but are not limited to: 1) Inculturation theologies were given less attention in the West but dialogue theologies after 9/11. 2) While contextual theologies feature well in global societies like the Society for Biblical Literature (SBL) and American Academy of Religion (AAR), Third World Theologies are hardly

\footnotetext{
35 Custer, "From Contextualization to Glocalization", 207.

36 De la Torre, "Identity Cross-Dressing while Teaching a Global Context", 89.

37 Byang Kato, Theological Pitfalls in Africa. Kasimu, Kenya: Kenya Evangelical Publishing house 1975.

38 Küster, "From Contextualization to Glocalization", 207.

39 Robert Schreiter, Constructing Local Theologies. Maryknoll, NY: Orbis, 1985.
} 
translated into European languages. Even the works written in English are published only in English and mostly by American publishers. 3) Publications of Third World theologians are more easily available in Western libraries than in the libraries of the countries of origin of their authors. There is therefore a problem of dissemination of Third World theologians' thoughts to where they are most needed. 4) That the "situation of Black Theology is again different. Its representatives, such as Desmond Tutu, Allan Boesak or Tinyiku (sic) Maluleke, are deeply involved in the great transformation processes South Africa is undergoing since the end of apartheid. They speak about reconciliation, reconstruction and reparation". ${ }^{40}$ Küster concludes this part of his argument by stating that theologians like Jesse N.K. Mugambi, Diego Irarrazaval, and Laurenti Magesa, among others, have a "wish to transform both the local cultures and the churches in response to globalisation" in common. ${ }^{41}$ But, is that really the intention of the theologians? Do they all agree on transforming local cultures and churches as a veritable response to globalisation?

Theologians of the Third World analysed by Küster and others not mentioned in his essay were and are aware of changes that have taken place around the globe. They have in one way or the other and by way of differing methods and constructions creatively initiated and engaged in discourses theologically to address the changing times and needs of their own people. Küster is able to 'read' this aspect in the discourses he reviewed. However, there are other perspectives he overlooked. It is true that Black Theology of Liberation has suffered a setback after 1994 when majority rule and a new constitution were put in place in South Africa. Boesak decries this situation, when he asks:

When the moment called, we went to prison for them (political activists) and shed our own blood for their cause, which was also ours, risked our lives for what we, and they, believed in. We made our sacrifices and inspired others to do likewise. Is the identification too close? Is it that when they falter, we fall, and when they fall, we fail? Is critique of the government too much self-critique? Is this the price we pay for having been so right in the struggle? These are deep, painful questions and the answers may disturb us more that we would want. But it is better to ask them now than to regret never having asked at all $\{$ my emphasis $\}{ }^{42}$

Boesak is reacting to the apparent loss of a prophetic voice and praxis that was loud and active during the struggle days and now appears to be muted since blacks themselves became subtle oppressors. But in the same essay, Boesak reiterates the continued relevance and significance of Black Theology, saying that "liberation theology, as an expression of African Christian theology, is as necessary now as it ever had been". ${ }^{43}$ Like his African American colleague and compatriot, Gayraud Wilmore, ${ }^{44}$ Boesak affirms that "black pride, black power, African nationalism and the struggle for black freedom, dignity and the African soul had no past without the religious faith of the African people and the prophetic church, and without them it may well have no enduring and meaningful future". 45

In taking up the prophetic voice of the church that Black Theology once had in South Africa, two young black theologians in South Africa, Rothney Tshaka and MK Makofane, argue that a distinction should be made between Black Theology of Liberation that exa-

\footnotetext{
Küster, "From Contextualization to Glocalization", 208.

Küster, "From Contextualization to Glocalization", 209.

Boesak, "Truth Crushed to Earth", 26.

Boesak, "Truth Crushed to Earth", 26.

Gayraud Wilmore, Black Religion and Black Radicalism, an Examination of the Black Experience in Religion.

New York, NY: Anchor Books (1973:231).

45 Boesak, "Truth Crushed to Earth", 27.
} 
mines spiritual and material conditions of the people on the margins of society and Black Theology as a symbolic intellectual discourse referring to humanity in its entirety. ${ }^{46}$ Whatever this distinction entails, the idea is that Black Theology, as a resistant voice of the people on the underside of history, is relevant and alive, and should remain an active discourse as long as the situation of vulnerability of people of colour persists. Desmond Tutu not only retired from Episcopal service, but he also retired to a large extent from public life, soon after his compatriot, the late Nelson Mandela did. However, it could still be argued that Tutu was guided by his anthropology that all are created in the image of God, and that God's dream for his created beings is the same for every race. Therefore, it is a sin for any race to discriminate against another. Where this has happened, as it was the case in South Africa before 1994 (on racial grounds) and in Rwanda during the 1994 ethnic genocide, reconciliation is the only hope for the future co-existence of all races and ethnic groups. ${ }^{47}$ If this is Tutu's point of view, then it may not be fair to conclude that his participation in nation building by serving as Chair of Truth and Reconciliation Commission (and other similar public engagements) under President Nelson Mandela lessened his contribution to Black Theological discourse. Never throughout his theological career and in public discourse, did Tutu change his position on Black Theology.

A similar argument could be advanced regarding African Theology. It is true, as Küster argues, that the initial zeal of the first generation of African theologians may not be seen in the contemporary discussants in African theological discourses. But to "lay down a hole does not mean one has stop to working". 48 These were words of acclaimed father of African Theology, John Mbiti in response to the question on the future of African Theology in the twenty-first century. The same year African Christian Theologies in Transformation was published, ${ }^{49}$ Maluleke and Nadar jointly called for essays on agency of the oppressed discourse, consciousness, liberation and survival in theological perspective which were published in Journal of Theology for Southern Africa (120). All six contributors to that special issue of the journal are black African males and females (Nadar being Indian South African female). The arguments of the discussants are that, in whichever way one looks at the situation of the oppressed, there is proven evidence that the oppressed, no matter the level of their destitution, have devised means of survival and resistance to be able to serve as agents of change in their lives and that of others. They are therefore agents themselves and should not be seen as being too weak or too poor to act for themselves or that they stand in need of others to speak for them. After all, the 'subaltern' does 'speak'. ${ }^{50}$ Perhaps this was a follow up on an earlier call by Maluleke, that it is time for Africans to "drink from their own wells". ${ }^{51}$ This is clear from Maluleke and Nadar's description of the notion of agency. By agency, they argue: "the basic suggestion is that human beings, even the most oppressed, marginalised and seemingly destitute among them, have the potential, possibility and even ability to act as (moral) agents of transformation and change in their

\footnotetext{
46 RS Tshaka \& MK Makofane, "The Continued Relevance of Black Liberation Theology for Democratic South Africa Today", Scriptura 105 (2010:532-546).

47 Tutu, Desmond, No Future without Forgiveness. A Personal Overview of South Africa's Truth and Reconciliation Commission. London: Rider 1999.

48 John Mbiti, "To lay down a hole does not mean one has to stop working", unpublished paper read during African Christian Theologies in Transformation Conference at University of the Western Cape, South Africa 4 to 6 June 2003.

49 Ernst Conradie (ed.) African Christian Theologies in Transformation. Stellenbosch: EFSA 2004.

50 Gayatri C Spivak, “Can the Subaltern Speak?” in: Marxism and the Interpretation of Culture, Gay Nelson \& L Grossberg (eds.). London: Macmillan (1988:271-313).

51 TS Maluleke, "Black African Theologies in the New World Order", 3-19.
} 
own lives and in the lives of others".52 In this way, the discussants opt to continue the consciousness movements of the $1970 \mathrm{~s}^{53}$ into the twenty-first century theological discourse, arguing that, if any discourse on blacks, women, Africans, or any people at the underside of history, is to be truly liberative, its agents must be from the communities that the discourse intends to liberate.

In the twentieth century, in the attempt to drink from their 'own wells', some African theologians constructed a number of theologies and hermeneutics that aim at addressing African problems by using African tools in an African way by Africans themselves. When Oduyoye speaks of an "irruption within an irruption" 54 she was not referring to the fact that what was going on in the Ecumenical Association of Third World Theologians was not on course. Rather, it referred to the fact that it was incomplete without women having a space to deal with their own specific issues, which could be argued, are numerous, and that men are not in a position to address them on behalf of women. Women, too, should "drink from their own wells". As such, Kanyoro, ${ }^{55} \mathrm{Upong}^{56}$, Dube, ${ }^{57}$ Masenya ${ }^{58}$ Phiri, ${ }^{59}$ and others from the Third world constructed their vernacular, also intercultural hermeneutics, not necessarily as a move away from contextualisation to globalisation, but rather, as a way of 'drinking' from their own 'wells'. 60

This is the point Maluleke makes, namely that the "twenty-first century challenges us to push the boundaries of Black and African theologies by isolating the crucial issues, mapping out the challenges and identifying past and current traps". ${ }^{1}$ According to Maluleke, "enough has been done already to lay a firm foundation upon which African theologies can build well into the twenty-first century". ${ }^{62}$ This would mean that the apparent absence of new theological constructions in Africa is not so much as a result of change in perspective on contextualisation in favour of globalisation, but rather that specific contextual challenges would determine what kind of theological discourse would meet African needs. This explains why Sano (citing late US Senator Hubert H. Humphrey) argues that "where you sit determines where you stand". ${ }^{63}$ Thus, where theologians from marginalised communities are sitting (their context) determines both their theology and hermeneutics.

However, it is not to say that all that theologians from the South have done should be taken and accepted without any criticisms. There appears to be as much criticism among theologians from the South in the twentieth century as ever before. In Africa, Maluleke

52 Maluleke \& Nadar, "Alien Fraudsters in the White Academy", 7-8.

53 Cf. Steve Biko, I Write what I like. Selection of his Works. Johannesburg: Ravan 1996.

54 Mercy Amba Oduyoye, "Christianity and African Culture", International Review of Missions LXXXIV:332/333 (January/April 1995:77-90).

55 Musimbi Kanyoro, Introducing Feminist Cultural Hermeneutics: African Perspective. London: Pilgrims Press 2002.

56 JS Ukpong, “ Rereading the Bible with African Eyes. Inculturation and Hermeneutics”, Journal of Theology for Southern Africa 91 (June 1995:3-14).

57 Musa Dube, Other Way of Reading: African Women and the Bible. Atlanta: Society of Biblical Literature 2001.

58 MadipoaneMasenya, "Struggling with Poverty/Emptiness: Rereading the Naomi-Ruth Story in African South Africa”, JTSA 120 (November 2004:466-59).

59 Isabel Apawo Phiri, "A Theological Analysis of the Voices of Teenage Girls on 'Men's Role in the Fight Against HIV/AIDS' in KwaZulu-Natal, South Africa”, JTSA 120 (November 2004:34-45).

Maluleke, "Black and African Theologies in the New World Order", 3-19.

61 Maluleke, "Black African Theologies in the New World Order", 3.

62 Maluleke, "Black and African Theologies in the New World Order", 3.

63 Sano, "Shifts in Reading the Bible", Semeia 90/91 (2002:105). 
laments that theologians on the continent (black, coloured or Indian) hardly agree on anything and he asks "why should they?"64 But in all they try to do, whether it is the likes of late Ghanaian theologian, Kwame Bediako, ${ }^{65}$ the Gambian-born, Lamin Sanneh, ${ }^{66}$ the Kenyan Jesse Mugambi ${ }^{67}$ or the South African Tinyiko Maluleke, ${ }^{68}$ the idea is to explore how the encounter between Christianity and the indigenous people of Africa shape each other and thereby solve or complicate already existing problems of the people who Christianity met on the continent. Whether they are successful or not should be a question that could be examined on the terms of the discussants of those discourses. It should also, be appreciated that the main goal of African theologians is to unearth (rediscover) African 'wells' while encouraging Africans to 'drink' from them themselves, in their theological discourses and hermeneutics. In all of these, context remains crucial.

\section{Conclusion}

A more careful 'reading' of theological discourses of resistant theologies that Küster rightly describes as Third World Theologies reveals a recurrent emphasis on context. Therefore, in as much as theologies from the South are mindful of global changes that are shaping global theological discourses, they still insist that the immediate context of the theologian provides the best hermeneutical lens to interpret and theologise for the context. The relevance of such theologies is determined by the extent to which they are in touch with real life situations as it is lived by the people within their context. If globalisation is taken seriously in the South, it is in the area of thinking globally but acting locally. Contextualisation remains a key in the methodological starting point of theologies from the underside of history.

\footnotetext{
64 Maluleke, "Black and African Theologies in the New World Order", 3-19.

65 Kwame Bediako, Jesus in African Culture. A Ghanaian Perspective. Accra: Asempa Publishers 1990.

66 Lamin Sanneh, Encountering the West. Christianity and the Global Cultural Context. Maryknoll, NY: Orbis 1993; Translating the Message: The Missionary Impact on Culture. Maryknoll, NY: Orbis 1989.

67 JNK Mugambi, From Liberation to Reconstruction: Africa Theology after the Cold War. Nairobi: East African Educational Publishers 1995.

68 TS Maluleke, ““A Morula Tree between Two Fields’: The Commentary of Selected Tsonga Writers on Missionary Christianity.” Unpublished DTh Thesis. Pretoria. University of South Africa 1995.
} 